\title{
Editorial
}

\section{PREPARING FOR THE EXPECTED}

As the world continues to be at war with the Covid-19 pandemic which challenges every public health resource including the well-being of fellow medical professionals, we, the JMUST editorial team give this special shout-out to all healthcare workers in the frontlines: Our hearts and every prayer go out to you as you bring every ounce of your expertise and unflagging spirit to save patients. May you and your loved ones be safe and protected. Very sadly, we salute those who succumbed to this disease while fulfilling their medical calling.

In March 2015, I was one of those who watched with interest Bill Gates' TED Talk on how we are not ready for the "next outbreak." Not to say that many health officials all over the world did not say the same thing, it just so happened that it was the technology giant and public health advocate, Gates, who talked about the need for pandemic preparedness using, among others, smart technologies.

Fast forward to today in May 2020, Covid-19's first wave has not only descended but overwhelmed much of the world's public health resources causing sickness, deaths and economic dislocation. Gates was right, the world was unprepared, but the world's best minds and efforts are working hard to stop the pandemic. Employed to help manage the viral spread are already existing smart technologies to educate the public on how to: prevent viral contact with social distancing, lockdown, get tested, isolate or quarantine, and get treated. Living with a pandemic in our midst, we all must learn to communicate better online.
I reflect on this, as now, on a daily basis, like my colleagues, I am on zoom or the like calls for meetings and online classes with medical students, on top of video and phone calls with patients and medical staff. Reliance on smart technologies is now the new norm in conducting most if not all types of transactions and engagements. Many, including me, have to speed up to reach some level of skill or savviness with these ubiquitous technologies, otherwise, communication is limited if not broken.

No such limitation or possible brokenness is happening with JMUST, however. With pride, I can say that we have prepared well with our dedicated electronic authoring and publishing features that are open access. JMUST's online submission of articles, editorial inputs and communications with authors and final publication has been set up almost three years ago. With training and practice, our JMUST team members are now quite experienced and have been electronically authoring and publishing with much success. Article submissions for every issue average more than a hundred. This would have been a nightmare if we continued using traditional print publishing with paper submissions and less than standard or unsecure online document sharing.

For this 2020 May issue, I am most grateful to the editorial team who truly overextended themselves to get this issue out on time considering the difficult demands of their medical work during this pandemic and the necessity of protecting their families during the lockdown. To the authors, thank you for your unwavering energy to respond to our questions and accordingly revisit your articles.

This present JMUST issue included seven original/ research articles, a systematic review and a case report. Expanding the journal reach and attuned to current times, we have incorporated tandem special article types. 
To all our readers, please keep well and stay informed. We will get through this pandemic with renewed hope in humanity's resilience and deeper appreciation for medical breakthroughs borne from painstaking research. (c) (i) Open Access This article is licensed under a Creative Commons Attribution 4.0 International License, which permits use, sharing, adaptation, distribution and reproduction in any medium or format, as long as you give appropriate credit to the original author(s) and the source, provide a link to the Creative Commons license, and indicate if changes were made. The images or other third party material in this article are included in the article's Creative Commons license, unless indicated otherwise in a credit line to the material. If material is not included in the article's Creative Commons license and your intended use is not permitted by statutory regulation or exceeds the permitted use, you will need to obtain permission directly from the copyright holder. To view a copy of this license, visit http://creativecommons.org/licenses/by/4.0/. 